\title{
A Quest for Experts' Consensus on the Geo-Education Module using Fuzzy Delphi Analysis
}

\author{
Mohd Faiz Mohd Yaakob ${ }^{1, *}$, Aliff Nawi ${ }^{1}$, Mat Rahimi Yusof ${ }^{1}$, Mohd Sofian Omar Fauzee ${ }^{1}$, \\ Hapini Awang ${ }^{2}$, Hareesol Khun-Inkeeree ${ }^{3}$, Mohd Affendi Ahmad Pozin ${ }^{4}$, Akhmad Habibi \\ ${ }^{1}$ School of Education and Modern Languages, Universiti Utara Malaysia, Malaysia \\ ${ }^{2}$ School of Computing, Universiti Utara Malaysia, Malaysia \\ ${ }^{3}$ School of Liberal Arts, Wilalak University, Thailand \\ ${ }^{4}$ School of Business Innovation and Technopreneurship, Universiti Malaysia Perlis, Malaysia \\ ${ }^{5}$ Faculty of Teacher Training and Education, Jambi University, Indonesia
}

Received March 18, 2020; Revised May 9, 2020; Accepted May 20, 2020

Copyright $(2020$ by authors, all rights reserved. Authors agree that this article remains permanently open access under the terms of the Creative Commons Attribution License 4.0 International License

\begin{abstract}
Education for sustainable development allows each modern humans being to obtain the information, skills, attitudes and principles necessary to shape a sustainable future. The word Geo derives from the Greek word meaning "earth," which can also be interpreted in the sense of land, global or Earth-related. The purpose of this study is to analyze expert consensus for the new educational module, Geo-Education. The objective of this study is to obtain from 12 expert views to build the questionnaire of Fuzzy Delphi Method (FDM) in 10 points Likert scale and consensus on Primer; Natural Ecosystem; Issues and Problems; Sustainable Lifestyle; and Cross-Curricular. The methodology of this research used quantitative fuzzy Delphi analysis. The instrument consists of five sections covering 25 review items for expert consensus. The findings show that experts have consensus agree on all 25 items exceeds $75 \%$, and all defuzzification values for each item exceeds the value of $\alpha$-cut $=0.5$. That means all those items are accepted by the experts. Fuzzy Delphi Method enhanced the accuracy of the questionnaire about Geo-Education module. This study has provided preliminary information on Geo-Education module aspects that need to be focused on Primary; Natural Ecosystem; Issues and Problems; Sustainable Lifestyle; and Cross-Curricular in the process of developing effective teaching and learning modules. The implication concludes that the Geo-Education Module can be used as guidance to the Ministry of Education Malaysia to supplement the teaching materials to teachers training institutes.
\end{abstract}

Keywords Fuzzy Delphi, Expert Consensus, Development Module, Teaching and Learning

\section{Introduction}

Many global initiatives have been introduced through various implementations and have been warmly welcomed by most countries, although some are still in the state of indolence towards achieving the objectives outlined [1]. The awareness regarding the importance of sustainable development in education should be emphasized beyond government and private agencies, whereby it should also be extended to the public. Indeed, it should even be introduced since the beginning, including at the school and university level. As such, there is an urgent need to rebrand Environmental Education and develop a specific module called Geo-Education. This Geo-Education module is suggested to be used by trainee teachers that will be their guide before jumping into the real work environment.

Sustainable development in education still fails to catch the attention of local researchers [2]. The implementation of sustainable development is still unclear despite being formally implemented in Malaysian primary and secondary education system since 2005 through the Sustainable School Program: Malaysian Environmental Award [3]. Some teachers are still confused by the concept of implementing sustainable development in education [4], [5].

Furthermore, unavailability of specific guidance from the professionals regarding the application of sustainable development has added insult to injury, and sometimes, this phenomenon leaves the teachers with no option but to ignore the aspect of sustainability [6]. Lack of awareness of information on the implementation of sustainable development in students' lives also affects the achievement of SDGs [7]. This indicates that a lack of guidelines has hindered teachers from implementing sustainable 
development in their teaching and learning. Therefore, this study aims to validate 'Geo-Education Module: Across Curriculum' based on the experts' consensus that will be the guideline for UUM trainee teachers during the practicum. This module will be developed with cross-curricular elements $(E M K)$ that can be embedded in all subjects at school. Moreover, it will expose trainee teachers to various aspects such as location, language, culture, ecology and human environment. This module should also guide trainees to integrate sustainability into all aspects of life in the school environment, whether administration, learning processes, building management, and commutations to and from school as well as school-community relationships.

\section{Literature Review}

\subsection{Geo-education}

The word Geo derives from the Greek word meaning "earth," which can also be interpreted in the sense of land, global or Earth-related. Meanwhile, the concept of Geo-Education is currently gaining public attention. This can be seen in the enormous progress in managing $8 \mathrm{Gs}$ like Geo-Heritage, Geo-Conservation, Geo-Sites/Geo-Parks, Geo-Management; Geo-Education; Geo-Tourism; and Geo-Diversity; [8]. In the context of education, Geo-Education is globally regarded as a platform that provides the current generation with a basic understanding of how the human and environment interact in regional and global contexts [9]. Malaysia has started to use the term 'Geo-Park' by introducing Langkawi UNESCO Global Geo-Park, which has been rapidly gaining popularity and become one of the contributors to the international and domestic tourism industry. Notwithstanding, in the context of education, Geo-Education is still uncommon among the public. Geo-Education is identical to Environmental Education, which needs to be rebranded in response to the call of Sustainable Development Goals (SDG) [10].

In recent years, sustainable education has become a necessity for local and international interests. For instance, this is being taken seriously by UNESCO that encourages the creativity, including in addressing current and future global challenges and to create more sustainable and resilient societies (UNESCO, 2016). Sustainable education enables students to integrate environmental considerations in making more informed decisions [11]. The Education Sustainable Development (ESD) approach in the context of education is also globally recognized as can be seen during the conference of The World Conservation Union (IUCN) with the concept of "education for sustainable living" in the late 1990s [12]. To this day, the United Nation continues to focus on the ESD with the execution of the United Nations Decade of Education for Sustainable Development (2005-2014), aimed to emphasis all countries on the importance of integrating sustainable development principles, values, and practices into all aspects of education and learning [13]. Nevertheless, key issues are surrounding this. Education for sustainable development (ESD) is generally a process for developing students' concerns, abilities, attitudes and values. This process enables them to effectively involve in sustainable development locally, nationally and internationally, which should prepare them towards a more sustainable future. Environmental issues need to be addressed through education. This is because education is a key agent in transforming society and promoting sustainable development [14-16].

Meanwhile, cross-curricular elements (EMK) are the added elements that are incorporated into the teaching and learning process, aiming at strengthening human capital skills and appearance. Sustainable development is seen as one of the most proactive and practical ideas of modern development that balance between the needs for development and environmental conservation [17]. The world community is concerned about issues of environmental exploitation, economic development and deteriorating quality of life [18]. Development activities that neglect the environmental aspects also threaten the future of generations. It is undeniable that this severe phenomenon is affecting the dependence, prosperity and sustainability of civilization [19].

In Malaysia, Environmental Education has been formally implemented through a well-planned curriculum since 1983 (Kurikulum Baru Sekolah Rendah, KBSR) and in 2012 through the Kurikulum Standard Sekolah Rendah (KSSR). Based on the long history of Cross-Curricular $(E M K)$ implementation in formal education, it can be concluded that Malaysia has successfully produced citizens who are exposed and aware of the environmental element. However, in reality, the application of environmental values is yet to be fully implemented by teachers in education, and thus the benefits of it are not obtainable by students [20].

The focus of the Sustainable School program is to strengthen the existing process of Environmental Education implementation by integrating environmental knowledge, skills and values into the curriculum and co-curriculum. Also, the Sustainable School program is expected to create a school environment that emphasizes the preservation and maintenance of school environment, home, community and country.

Furthermore, a good $E M K$ will facilitate teachers in delivering efficient teaching methods and thus generate good human capital and ultimately leads to a sustainable lifestyle. This indicates the important role of education in creating a sustainable lifestyle. In light of this, it is equally important to note that the education here is referred to EMK module. These EMK elements have presently taken place at schools and should be extended to higher education institutions. Therefore, in line with the current trend of developing empirically studied modules, there is a 
need to research sustainable education module as well.

\section{Research Methodology}

This is a quantitative study using survey design, which used 12 field experts as samples. The instrument distributed to experts was a set of questionnaires consisting of five items to measure five constructs. To implement the Fuzzy Delphi technique in this study, the researcher first identified and organized the modified items from the need analysis into an organized and orderly form for the experts to review. Subsequently, the researcher determined a group of experts who agreed to contribute their expertise in expressing ideas, criticizing and improving the content of the items determined earlier. The researcher distributed the questionnaires containing the items obtained through the needs analysis and the experts were asked to state the level of agreement on each item whether strongly agree, agree, slightly agree, disagree and strongly disagreed. After all, experts have indicated their level of agreement; they were also required to provide their views on each item in the questionnaire form. Data from the Likert Scale were then transformed into Fuzzy number and analyzed using Microsoft Excel software. This data analysis technique is known as the Fuzzy Delphi technique or the Fuzzy Delphi Method (FDM). Although the Delphi Technique has been widely applied in education, especially in predicting the future, this method has its drawbacks. Among the disadvantages of the Delphi method are [21], 1) Data reliability depends on expertise; if the researcher fails to provide the actual/credible experts, then the study will lose its credibility, 2) The experiment is repeated on the same sample, and this will result in the constant feeling among them, 3) A small number of experts will not solve all the problems under investigation, and 4) Lack of response in the emotional aspect.

To address the issue of ambiguity/fuzziness in expert consensus, researchers from around the world have invented new methods. [22] proposed the application of the Fuzzy Delphi Method Theory into semantic variables used to solve the problem of ambiguity/fuzziness in Delphi Techniques. The Fuzzy Delphi method was proposed to solve problems in the traditional Delphi Technique. This theory has been introduced to enhance the use of time and to solve general understanding with expert opinion [23]. Ishikawa works using the minimum-maximum method together with cumulative frequency distribution and fuzzy scoring to organize members' opinions into fuzzy numbers. The expert interval value is then used to obtain the fuzzy numbers that result in FDM. This method is based on the opinion of a group of qualified experts who guarantee the validity of the information collected.

[24] proposed a Fuzzy aggregate equation. Using the functions of this equation, the similarities between the experts' opinions can be compiled and the fuzzy numbers can be directly assigned to each expert to determine the level of agreement between them. Then a consensus coefficient is used to obtain assessments' fuzzy values of all experts. If the level of agreement among experts is too low, then the questionnaire must be administered again. The advantages of the Fuzzy Delphi Method are; 1) save time on the questionnaire, 2) cost-effective, 3) reduce the number of surveys, questionnaire increase the rate of recovery, 4) experts can fully express their opinions, ensure the completeness and consistency of opinions and 5) reduce inevitable fuzziness occurrences the study. Moreover, this method guarantees the accuracy of expert panels' opinions of them as they give real responses.

\subsection{Development of Geo-Education Module}

The Sustainable Development Goals (SDGs) has become a global agenda since its introduction in early 2016, where the United Nations outlines 17 goals that all nations should achieve by 2030 . Known as the agenda for human prosperity, SDGs are a continuation of the Millennium Development Goals (MDGs) and cover all issues of sustainable development. Also, several important goals of sustainable development have been agreed upon including; 1) there will be no more poverty and hunger, 2) health and well-being, 3) quality education, 4) gender equality, 5) clean water, 6) clean energy; 7) employment and economic growth, 8) industrial resilience, 9) reduce inequality, 10) sustainable city, 11) responsible utilization, 12) carbon reduction, 13) life on land and sea, 14) fair governance and peacefulness, and 15) partners in achieving sustainability goals.

Geo-Education development is an adaptation of the Environmental Education Module. Five major constructs in Geo-Education are Primary, Natural Ecosystems, Issues and Problems, Sustainable Lifestyle and Cross-Curricular.

\section{A) PRIMER}

P1: Geo-Education should be introduced to trainee teachers through the special module.

P2: There are requirements in terms of learning outcomes for the Geo-Education module.

P3: Technology applications need to be embedded in Geo-Education learning.

P4: An appropriate approach should be applied for the Geo-Education module.

P5: Geo-Education needs to be understood by trainee teachers.

\section{B) NATURAL ECOSYSTEM}

E1: The natural ecosystem is a crucial element of Geo-Education.

E2: We live in a natural ecosystem.

E3: The natural ecosystem needs to be well preserved.

E4: There is a responsibility to protect the natural 
ecosystem.

E5: We are entrusted to protect the natural ecosystem.

\section{C) ISSUES AND PROBLEMS}

S1: There are frequently debated issues in Geo-Education. S2: Geo-Education takes place around us.

S3: Environmental pollution is a significant issue of Geo-Education.

S4: Global warming is an issue in Geo-Education.

S5: Geo-Education issues are very relevant to educational institutions.

\section{D) SUSTAINABLE LIFESTYLE}

G1: We need to know a sustainable lifestyle.

G2: Sustainable lifestyles need to be practised by us.

G3: Sustainable life is significant to us.

G4: Nature needs us to take good care of it.

G5: The technology development needs to be consistent with a sustainable lifestyle.

\section{E) Cross-Curricular}

M1: Geo-Education can be taught on various subjects.

M2: Geo-Education can be cross-curricular.

M3: Various techniques can be introduced for

Geo-Education teaching.

M4: Geo-Education is suitable as a cross-curricular element.

M5: Geo-Education is suitable for teaching and learning of all subjects in school.

\subsection{Experts' Information}

During this phase, a panel of experts is selected through purposive sampling to evaluate the module. In the Delphi method, the selection of experts is the most crucial step as it will influence the quality of findings [25]. Lecturers with more than five years' experience are classified as experts because they have continuous teaching experience [26]. Furthermore, [27] added that expert in education refers to an individual with over five years of experience in their specific field/area. In order to achieve specific goals, [28] suggested using a panel consisting of five to ten experts. On the other hand, [29] recommended 10 to 18 experts to validate the model. According to [30], the number of experts selected should be between 15 and 35 experts to ensure comprehensive and reliable research findings. Thus, after considering the other relevant factors, the number of experts selected to evaluate and validate the model was 12 individuals.
Table 1. Experts' Background

\begin{tabular}{|ccc|}
\hline Category & & Frequency \\
\hline \multirow{2}{*}{ Gender } & Male & 7 \\
Teaching & Female & 5 \\
Experience & More Than 5 Years & 12 \\
& & \\
Academic & PhD & 9 \\
Qualification & Master's Degree & 3 \\
& Bachelor's Degree & 0 \\
& Diploma & 0 \\
Institution & University & 3 \\
& Institute of Teacher Education & 7 \\
\hline
\end{tabular}

\section{Analysis and Finding}

In the Fuzzy Delphi technique, there are two terms to be understood; Triangular Fuzzy Number and Defuzzification process. Triangular Fuzzy Number represents the values of $\mathrm{m} 1, \mathrm{~m} 2$ and $\mathrm{m} 3$ and is written as follows $(\mathrm{m} 1, \mathrm{~m} 2, \mathrm{~m} 3)$. The $\mathrm{m} 1$ represents minimum value, $\mathrm{m} 2$ represents logical value, while $\mathrm{m} 3$ represents the maximum value. The Triangular Fuzzy Number is used to produce a Fuzzy scale (similar to a Likert scale) to translate linguistic variables into fuzzy numbers. Equally important, the levels for Fuzzy scale should be in odd numbers. The higher the Fuzzy scale, the more accurate the data obtained. This is explained in Figure 1 .

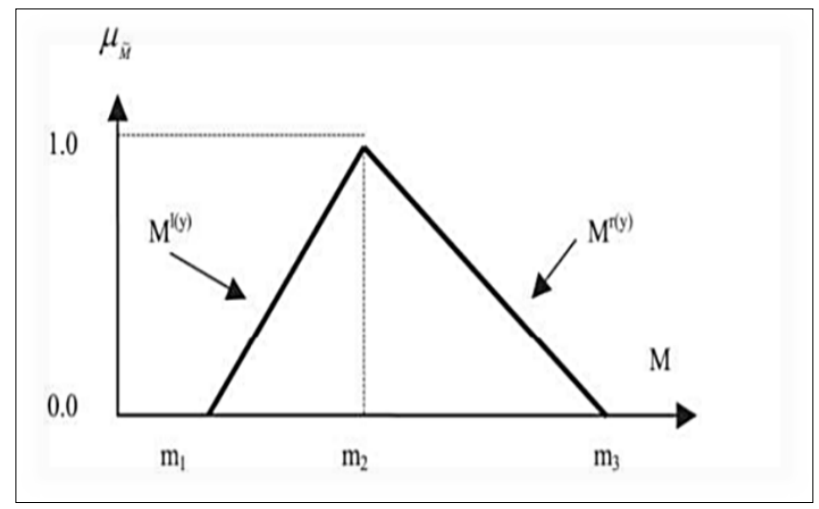

Figure 1. Fuzzy scale agreement levels.

In this study, the process of collecting and analyzing data using Fuzzy Delphi technique was performed when the experts were given the instrument, and each item was represented on a Likert scale as well as a blank space for expert comments and suggestions. Likert scale data obtained will be analyzed in Excel program. All data is converted into a Triangular Fuzzy Number. The five-point Fuzzy scale was used in this study. This can be seen in Table 2. 
Table 2. Five-Point Fuzzy Scale

\begin{tabular}{|cc|}
\hline Level of Agreement & Fuzzy Scale \\
\hline Strongly Disagree & $0.0,0.0,0.2$ \\
Disagree & $0.0,0.2,0.4$ \\
Slightly Agree & $0.2,0.4,0.6$ \\
Agree & $0.4,0.6,0.8$ \\
Strongly Agree & $0.6,0.8,1$ \\
\hline
\end{tabular}

Table 1 depicts the higher the number on the scale, the more accurate the data obtained. This study selected the five-point linguistic scale, as shown in Table 2. Furthermore, the obtained Fuzzy values are Strongly Disagree: 0.0, 0.0, 0.2, Disagree: 0.0, 0.2, 0.4, Slightly Agree: $0.2,0.4,0.6$, Agree; 0.4, 0.6, 0.8, and Strongly Agree: $0.6,0.8 .1$. The data were then tabled to acquire Fuzzy values (n1, n2, n3) and Fuzzy average values (m1, $\mathrm{m} 2, \mathrm{~m} 3)$, which were used to obtain threshold values, expert consensus percentages, defuzzification and item rankings. To obtain expert consensus for each item, the threshold values should not exceed 0.2. On the other hand, the percentage of experts' consensus should exceed $75 \%$ while the defuzzification value for each item should exceed $\alpha$-cut $=0.5$. To obtain a threshold value, the distance between two Fuzzy numbers is determined using the following formula:

$$
d(\tilde{m}, \tilde{n})=\sqrt{\frac{1}{3}\left[\left(m_{1}-n_{1}\right)^{2}+\left(m_{2}-n_{2}\right)^{2}+\left(m_{3}-n_{3}\right)^{2}\right]} .
$$

The $d$ is a threshold value. The value $\leq 0.2$ means that all the experts reached an agreement on the particular item. Conversely, if the condition is not achieved, a second-round is required to determine the necessity of the item. Fuzzy Delphi technique also involves the process of determining the expert's agreement whether it exceeds or equals $75 \%$ of the entire constructs or for each item. Each item is assumed to reach expert consensus if the percentage is equal to or greater than $75 \%$ [31]. Furthermore, the defuzzification process was also carried out during data analysis using the Fuzzy Delphi technique. It is the process of determining the position or priority of each item or of determining the position of each variable or sub-variable. In this process, there are three formulas namely;

i. $A=1 / 3 *(m 1+m 2+m 3)$,

or, ii. $A=1 / 4 *(m 1+2 m 2+m 3)$,

or, iii. $A=1 / 6 *(m 1+4 m 2+m 3)$.

The value of $\alpha$-cut $=$ median for ' 0 ' and ' 1 ', where $\alpha$-cut $=$ $(0+1) / 2=0.5$. If the value of A is less than $\alpha$-cut $=0.5$, the item will be rejected because it indicates the experts' agreement to reject the item. Conversely, if the A value exceeds the $\alpha$-cut $=0.5$, the item will be accepted as it indicates the expert consensus to retain it [32]. Besides, the rationale of choosing Fuzzy Delphi compared to the traditional Delphi technique in this study is its advantages in terms of time and cost savings in administering the questionnaire. It also enables experts to fully and consistently express their views [33]. The threshold value (d), percentage of expert consensus, defuzzification and item rankings of the Primer construct items are shown in Table 3.

\section{A. Primer}

The results of the primary constructs are described in three ways as the item value exceeds the threshold value (d) $=0.2$; Expert approval percentage exceeded $75 \%$ and defuzzification value per item exceeded $\alpha$-cut $=0.5$. By the first method, items P1; P2; P4 and P5 exceeded the threshold value (d) $=0.2$ and only item P3 had a threshold value (d) $\leq 0.2$. If the average value and expert rating is less than the threshold value of 0.2 , the item has gained expert consensus [35]. Percentage of expert approval shows that all items exceed $75 \%$. All defuzzification values for each item also exceeded the $\alpha$-cut $=0.5$ value. This shows that the items of primary construction analysis received consensus from the experts. The overall findings are presented in Table 3.

Table 3. Threshold Value (d), Percentage of Experts' Consensus, Defuzzification and Items Ranking of Primer Construct

\begin{tabular}{|c|c|c|c|c|c|}
\hline \multirow[t]{2}{*}{ Expert } & \multicolumn{5}{|c|}{ Item } \\
\hline & $\mathrm{P} 1$ & $\mathrm{P} 2$ & P3 & $\mathrm{P} 4$ & P5 \\
\hline 1 & 0.051 & 0.076 & 0.000 & 0.025 & 0.102 \\
\hline 2 & 0.051 & 0.076 & 0.000 & 0.025 & 0.102 \\
\hline 3 & 0.051 & 0.076 & 0.000 & 0.280 & 0.509 \\
\hline 4 & 0.051 & 0.229 & 0.000 & 0.025 & 0.102 \\
\hline 5 & 0.051 & 0.229 & 0.000 & 0.025 & 0.204 \\
\hline 6 & 0.051 & 0.076 & 0.000 & 0.025 & 0.102 \\
\hline 7 & 0.051 & 0.076 & 0.000 & 0.025 & 0.102 \\
\hline 8 & 0.051 & 0.076 & 0.000 & 0.025 & 0.102 \\
\hline 9 & 0.051 & 0.076 & 0.000 & 0.025 & 0.102 \\
\hline 10 & 0.255 & 0.076 & 0.000 & 0.025 & 0.102 \\
\hline 11 & 0.051 & 0.076 & 0.000 & 0.025 & 0.102 \\
\hline 12 & 0.255 & 0.229 & 0.000 & 0.025 & 0.204 \\
\hline $\begin{array}{l}\mathrm{d} \text { value of each } \\
\text { item }\end{array}$ & 1.018 & 1.375 & 0.000 & 0.560 & 1.833 \\
\hline $\begin{array}{c}\text { Threshold value (d) } \\
\text { of construct }\end{array}$ & 0.080 & & & & \\
\hline $\begin{array}{l}\text { Percentage of } \\
\text { experts' consensus } \\
\text { on each item }\end{array}$ & $83 \%$ & $75 \%$ & $100 \%$ & $92 \%$ & $75 \%$ \\
\hline $\begin{array}{l}\text { Average Experts' } \\
\text { Consensus }\end{array}$ & $85 \%$ & & & & \\
\hline $\begin{array}{l}\text { Percentage of All } \\
\text { Items }\end{array}$ & & & & & \\
\hline $\begin{array}{c}\text { Defuzzication } \\
\text { (Average of Fuzzy } \\
\text { response) (Alpha - } \\
\text { cut) }\end{array}$ & 0.767 & 0.750 & 0.800 & 0.783 & 0.733 \\
\hline Ranking & 3 & 4 & 1 & 2 & 5 \\
\hline Threshold va & (d) $\leq 0$. & [47] & & & \\
\hline Expert Group & onsense & Percent & $e \geq 75^{\circ}$ & [36] & \\
\hline All alpha $-\mathrm{Cu}$ & alues fo & each it & excee & $=0.5$ & \\
\hline
\end{tabular}

The data analysis, as shown in Table 3, indicates there are threshold values that exceed the threshold value of 0.2 ( $>$ 0.2 ). This means that there is disagreement in expert 
opinions and does not reach a consensus on certain items. However, the average value of all items of academic dishonesty factor shows a threshold value (d) of $<0.2$, which is 0.080 . If the obtained average threshold value (d) is less than 0.2 , then the item is considered to reach the experts' consensus [35]. Meanwhile, the overall percentage of expert consensus stands at $85 \%$ of which is above (> $75 \%$ ), illustrates that it meets the requirement of expert consensus on this item. Additionally, all Alpha-Cut (average of fuzzy response) values exceed $\alpha$-cut $=>0.5$. According to [36], the value of alpha cut should be greater than 0.5 and if less than 0.5 , then it should be dropped. The results of this analysis show that the items of the Primer construct have achieved the of level of experts' consensus. The items that were agreed upon by the expert consensus were sorted according to ranking, as shown in table 4 .

Table 4. Item Position Based on Ranking

\begin{tabular}{|c|c|}
\hline Item & Rank \\
\hline $\begin{array}{l}\text { P1: Geo-Education should be introduced to trainee } \\
\text { teachers through the special module. }\end{array}$ & 3 \\
\hline $\begin{array}{l}\text { P2: There are requirements in terms of learning } \\
\text { outcomes for the Geo-Education module. }\end{array}$ & 4 \\
\hline $\begin{array}{l}\text { P3: Technology applications need to be embedded in } \\
\text { Geo-Education learning. }\end{array}$ & 1 \\
\hline $\begin{array}{l}\text { P4: An appropriate approach should be applied for the } \\
\text { Geo-Education module. }\end{array}$ & 2 \\
\hline $\begin{array}{l}\text { P5: Geo-Education needs to be understood by trainee } \\
\text { teachers. }\end{array}$ & 5 \\
\hline
\end{tabular}

In the item rankings, the arrangement based on experts consensus ratings from highest to lowest are $\mathrm{P} 3, \mathrm{P} 4, \mathrm{P} 1, \mathrm{P} 4$ and P5. P3 states that green technology applications need to be incorporated into Geo-Education learning. The technology application is overgrowing and is gaining attention in the current education system [37]. In facing the current challenges of industrial 4.0, education is unavoidably related to technology. Information and Communication Technology (ICT) has delivered significant changes in education, especially in the aspect of teaching and learning (PnP). Therefore, the application of technology is crucial to make the teaching and learning process more exciting and useful.

Meanwhile, P4 stated that appropriate approaches should be used for the Geo-Education module. A variety of teaching and learning approaches can be implemented by teachers in the classroom. For example, 'play while learning' approach has the potential to be applied in preschools to ensure effective teaching and learning of language skills [38]. Imagination and creativity are the natural potentials of each child that has to be developed and nurtured deliberately. This should be done from the beginning of school through a variety of teaching and learning methods and approaches [39]. The goal of education lies in national education philosophy. In light of this, whether preschool or university, the aim is similar, which is to fully and integrally develop human potential in many aspects through fun, creative, safe, productive and meaningful learning environment [40]. As such, if children are not given the opportunity to develop and express creative ideas, to use creative approaches or to use materials creatively, then their natural creativity will be diminished.

On the other hand, P1 mentioned that Geo-Education needs to be introduced to trainee teachers through specialized modules. This is because the existing Environmental Education module is continuously being updated, and various new models have been developed [41]. However, the most challenging part in environmental ethics is to educate people to maintain a positive and harmonious attitude towards the right course of action that takes into account the environmental importance [42]. Various methods have been developed as educational tools and processes that can be used as a starting point for teaching plan and to foster Green Building education [43]. In conclusion, Environmental Education continues to be studied, especially in the context of challenges to plan the implementation and outline the lesson potentials that will enhance this effort in the Faculty of Education [44].

Next, P2 stated that there is a need for learning outcomes for the Geo-Education module. Undeniably, teaching and learning activities are closely related to learning outcomes. Learning outcomes are important because education plays a significant role in protecting the environment.

Finally, experts rate $\mathrm{P} 5$ as the lowest rating through the sentence: Geo-Education needs to be understood by the trainee teachers. All trainee teachers who undergo training at Teachers Traning (IPG) will follow the elements of teaching practices curriculum (Practicum) as a part of Professional Practices Component. During this practicum, all theories and knowledge learned need to be applied during as teaching practices. Hence, the teacher training curriculum at the Institute of Teacher Education (IPG) needs to be structured and improved towards enhancing the knowledge of trainee teachers while studying there [45]. Besides, trainee teachers play an essential and strategic role in education before graduating and being enrolled as real teachers in schools. Therefore, they need to take into account the importance of micro-teaching as early as during the training of teaching [46].

\section{B. Natural Ecosystem}

The finding from Natural Ecosystem construct is described in three ways as the item value exceeds the threshold value (d) $=0.2$, experts' consensus percentage exceeded $75 \%$ and defuzzification value per item exceeded $\alpha$-cut $=0.5$. In the first method, items P1, P2, P4 and P5 exceeded the threshold value (d) $=0.2$ and only item P3 had a threshold value (d) $\leq 0.2$. The average value and expert rating less than the threshold value of 0.2 indicate that the item has gained expert consensus [35]. In addition, all items exceeded the $75 \%$ value and all defuzzification values for each item are also exceeded the $\alpha$-cut value $=0.5$. This 
showed that the items of Natural Ecosystem achieved experts' consensus. The overall findings are presented in Table 5 .

Table 5. Threshold Value (d), Percentage of Experts' Consensus, Defuzzification and Items Ranking of Natural Ecosystem Construct

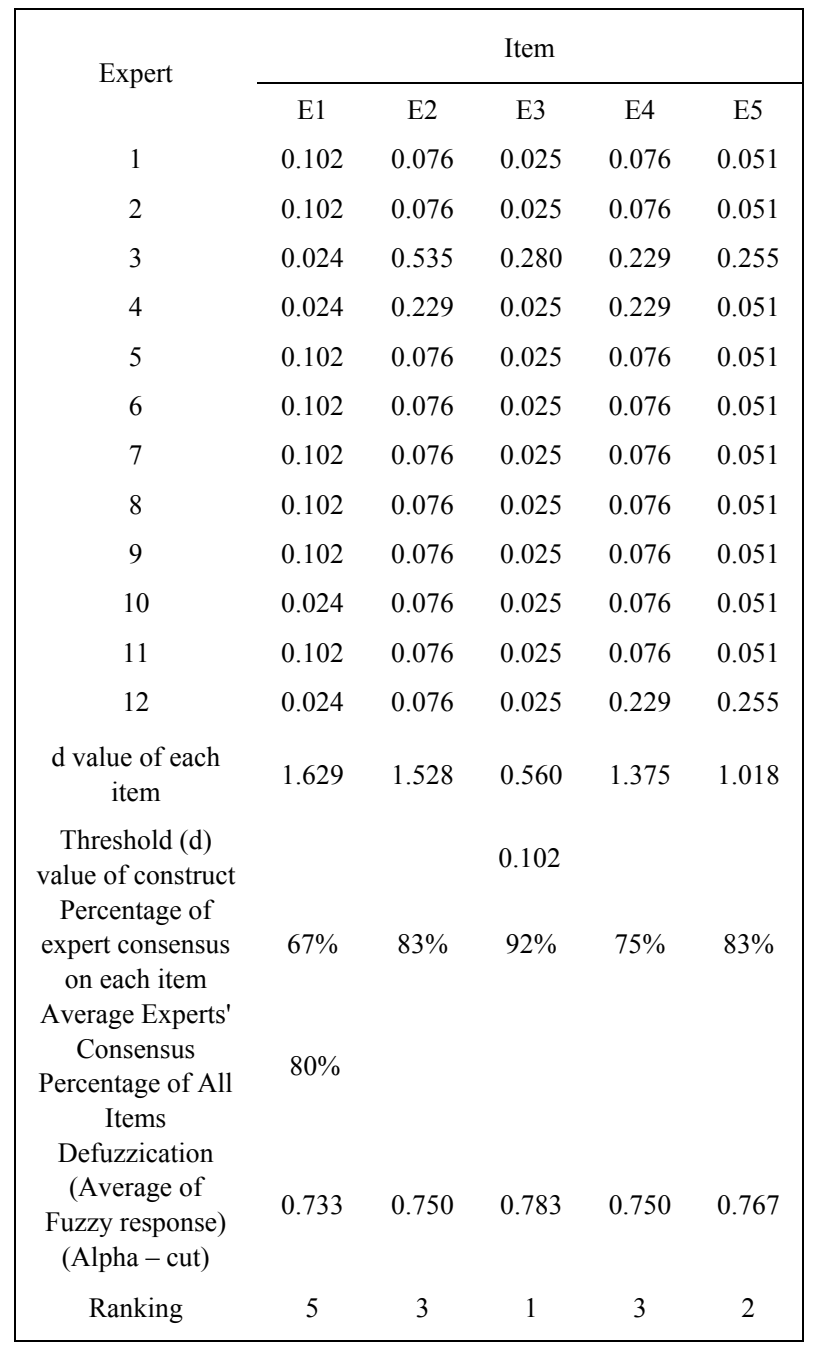

As shown in Table 5, some items exceed the threshold value of $0.2(>0.2)$. This means that there are contradictory expert opinions that did not reach a consensus on certain items. However, the average value of all items shows a threshold value of (d) $<0.2$, which is 0.102 . If the average threshold value (d) is obtained less than 0.2 , then the item has reached an excellent expert consensus [35]. Meanwhile, the overall percentage of expert consensus stands at the value of $80 \%$, which is above $(>75 \%)$, meaning that it meets the requirement of expert consensus on this item. Furthermore, all Alpha-Cut (average of fuzzy response) values exceed $\alpha$-cut $=>0.5$. According to [36], [32] the value of alpha cut should be greater than 0.5 and if less than that, then it should be eliminated. The results of this analysis show that the items of Natural Ecosystem construct have received a good experts' consensus. The items that are agreed by experts were sorted according to rankings, as shown in Table 6.
Table 6. Item Position Based on Ranking (Natural Ecosystem)

\begin{tabular}{|c|c|}
\hline Item & Rank \\
\hline $\begin{array}{l}\text { E1: The natural ecosystem is an essential element of } \\
\text { Geo-Education. }\end{array}$ & 5 \\
\hline E2: We live in a natural ecosystem. & 3 \\
\hline $\begin{array}{l}\text { E3: The natural ecosystem needs to be well } \\
\text { preserved. }\end{array}$ & 1 \\
\hline $\begin{array}{l}\text { E4: There is a responsibility to protect the natural } \\
\text { ecosystem. }\end{array}$ & 3 \\
\hline E5: We are entrusted to protect the natural ecosystem. & 2 \\
\hline
\end{tabular}

In the item rankings, the highest to lowest expert ratings were E3, E5, E2, E4 and E1. E3 states that Natural ecosystems need to be well maintained or preserved. In this sense, recover and maintain are interrelated words. The concept of recovery is used when something is damaged, while maintaining, taking care or preserve the quality of something. Natural ecosystems need to be well maintained in order to maximize economic and social importance somewhat and unobtrusively [48]. At the same time, the term Green Technology should not only be viewed in the context of protecting and recovering ecology. More importantly, it should be concentrated on the context of maintaining and improving the standard of living as well as the efficiency of human survival which is also an aspect of the ecology [49]. In the same sense, ecosystems are also made up of biological factors that depend on each other, namely biological factors and physical factors [50].

Meanwhile, E5: We are entrusted to protect the natural ecosystem. Trust is a noble thing that should be interpreted by exercising good practices such as not harming nature. Indeed, nature is a trust in humankind.

E2 and E4 share the same value. The responsibility as a human in an ecosystem is enormous. Hence, the environmental value system describing the principles of proper conduct needs to be built. We, as humans, have a clear relationship with the environment and act as the basis for resolving any conflicts of interest between humans and the environment. Meanwhile, [51] have proposed another premise of environmental value orientation besides anthropocentric and ecocentric, namely egocentric. Egocentric view nature as wholly owned by humans; it must be maintained for the sake of human well-being. In this context, the ecosystem of nature needs to be maintained by humans for their survival. The rapid development of human civilization has led to human reliance on the world of science and technology. Unfortunately, this deterioration has caused human beings to neglect their responsibility to protect the environment. Not to mention, irresponsible development and attitudes of society have negatively impacted the environment. The quality of human life will also decrease.

Finally, E1: The natural ecosystem is an essential element of Geo-Education. As a result of greed exploitation on this nature beyond religious guidance, natural ecosystem is disturbed and cannot be maintained. Global warming, environmental pollutions, climate change, 
landslides, flash floods, tsunami storms, acid rains, earthquakes, etc., all contribute to the instability of the ecosystem created by human hands [52]. The natural ecosystem is an integral part of Geo-Education. Meanwhile, [53] stated that natural disruption or small disturbance on ecosystem stability is usually under controlled conditions and are capable of recovering naturally.

\section{Issues and problem}

The finding of Issues and Problem construct is described in three ways as follows; (i) the item value exceeded the threshold value (d) $=0.2$, (ii) expert consensus percentage exceeded $75 \%$ and (iii) defuzzification value per item exceeded $\alpha$-cut $=0.5$. In the first method, items P1, P2, P4 and P5 exceeded the threshold value $(d)=0.2$ and only item P3 had a threshold value (d) $\leq 0.2$. [35] stated that if the average value and expert rating is less than the threshold value of 0.2 , then the item is considered to gain expert consensus. All items exceeded the $75 \%$ value. All defuzzification values also exceeded the $\alpha$-cut value $=0.5$. This showed that the items on Issues and Problems construct have a consensus from the experts. The overall findings are presented in Table 7.

Table 7. Threshold Value (d), Percentage of Experts' Consensus, Defuzzification and Items Ranking of Issues and Problem Construct

\begin{tabular}{|c|c|c|c|c|c|}
\hline \multirow{2}{*}{ Expert } & \multicolumn{5}{|c|}{ Item } \\
\hline & $\mathrm{S} 1$ & $\mathrm{~S} 2$ & $\mathrm{~S} 3$ & $\mathrm{~S} 4$ & S5 \\
\hline 1 & 0.458 & 0.178 & 0.127 & 0.178 & 0.127 \\
\hline 2 & 0.153 & 0.127 & 0.127 & 0.178 & 0.127 \\
\hline 3 & 0.153 & 0.178 & 0.484 & 0.433 & 0.178 \\
\hline 4 & 0.153 & 0.178 & 0.127 & 0.127 & 0.127 \\
\hline 5 & 0.153 & 0.127 & 0.178 & 0.127 & 0.178 \\
\hline 6 & 0.153 & 0.127 & 0.127 & 0.178 & 0.127 \\
\hline 7 & 0.153 & 0.127 & 0.178 & 0.178 & 0.178 \\
\hline 8 & 0.153 & 0.127 & 0.127 & 0.178 & 0.127 \\
\hline 9 & 0.153 & 0.127 & 0.127 & 0.127 & 0.127 \\
\hline 10 & 0.153 & 0.127 & 0.127 & 0.127 & 0.178 \\
\hline 11 & 0.153 & 0.127 & 0.127 & 0.178 & 0.127 \\
\hline 12 & 0.153 & 0.178 & 0.178 & 0.127 & 0.178 \\
\hline $\mathrm{d}$ value of each item & 2.139 & 1.782 & 2.037 & 2.139 & 1.782 \\
\hline $\begin{array}{c}\text { Threshold }(\mathrm{d}) \text { value } \\
\text { of the construct }\end{array}$ & 0.165 & & & & \\
\hline $\begin{array}{c}\text { Percentage of expert } \\
\text { consensus on each } \\
\text { item }\end{array}$ & $92 \%$ & $100 \%$ & $92 \%$ & $92 \%$ & $100 \%$ \\
\hline Average Experts' & & & & & \\
\hline $\begin{array}{c}\text { Consensus } \\
\text { Percentage of All } \\
\text { Items }\end{array}$ & $95.2 \%$ & & & & \\
\hline $\begin{array}{c}\text { Defuzzication } \\
\text { (Average of Fuzzy } \\
\text { response) (Alpha - } \\
\text { cut) }\end{array}$ & 0.700 & 0.717 & 0.717 & 0.683 & 0.717 \\
\hline Ranking & 4 & 1 & 1 & 5 & 1 \\
\hline
\end{tabular}

As shown in Table 7, some items exceed the threshold value of $0.2(>0.2)$. This means that there are inconsistencies in expert's opinions and not reaching consensus on certain items. However, the average value of all items in the construct of Issues and Problems shows a threshold value of $(\mathrm{d})<0.2$, which is 0.165 . If the average threshold value (d) is obtained less than 0.2 , then the item has reached an excellent experts' consensus [35]. Meanwhile, the overall percentage of expert consensus was at $95.2 \%$ of the agreement, which is above $(>75 \%)$ and met the requirements of experts' consensus on this particular item. Additionally, all Alpha-Cut (average of fuzzy response) values exceed $\alpha$-cut $=>0.5$. According to [36], [32] the value of alpha cut should be greater than 0.5 and if less than 0.5 , then it should be dropped. The findings of this analysis show that the items in the construct of Issues and Problems have received a good deal of experts' consensus. Items agreed by expert consensus were sorted according to rankings, as shown in table 8.

Table 8. Item Position Based on Ranking (Issues and Problems)

\begin{tabular}{|lc|}
\hline \multicolumn{1}{|c|}{ Item } & Rank \\
\hline \hline S1: There are frequently debated issues in & 4 \\
Geo-Education. & 1 \\
S2: Geo-Education takes place around us. & 1 \\
S3: Environmental pollution is a major issue of & 5 \\
Geo-Education. & 1 \\
S4: Global warming is an issue in Geo-Education. & \\
S5: Geo-Education issues are very relevant to \\
educational institutions.
\end{tabular}

The highest to the lowest experts' ratings were $\mathrm{S} 2, \mathrm{~S} 3, \mathrm{~S} 5$, $\mathrm{S} 1$ and S4. S2, S3 and S4 have the same agreement value on their ranking. Whether we realize or not, Geo-Education is happening around us. The United Nation (UN) states that more than 80 percent of human waste generated by human activities is discharged into rivers or seas without any treatment to reduce pollution. This indirectly raises the issue of river pollution [54]. Meanwhile, when a city undergoes urbanization, migration and population growth will take place, which will affect the condition and quality of the river. Globally, there are several initiatives to save the earth from increasing damages by environmental pollution and unpredictable climate and global warming [55]. The reported 4,611 open burning cases happening in 2013, which 858 cases involving agricultural areas, 739 forest fires and 640 bush fires [56]. Educational institutions offer a variety of change agents, and Geo-Education is closely linked to these institutions. The assessment tools that support educational institutions continue to be developed to monitor, manage and transform society [57]. Accordingly, education is regarded as a basis for achieving environmental awareness among students [58]. In other words, education is a fundamental tool for environmental control and sustainable development [59]. Also, Environmental Education is an appropriate medium to disseminate information, develop skills, encourage participation and stimulate decisive action on biodiversity [60]. 
Meanwhile, S1 says that there are issues that are frequently debated in Geo-Education. It is commonly known that a clean environment guarantees the comfort and well-being of its residents. However, a clean environment that is an environment that is free from any kind of pollution requires constant maintenance and changes in the environment quality have posed many threats to human health and wellness around the world, especially in terms of water scarcity, rising infectious diseases, food shortages, natural disasters, and urban congestion. Environmental issues are common in this country, especially issues causing river pollution [61].

Finally, S4: Global warming is an issue in Geo-Education. Besides, it causes the rise of global sea level, polar ice melt, and rising of sea salt level that causes coral bleaching [62].

\section{Sustainable lifestyle}

Table 9. Threshold Value (d), Percentage of Experts' Consensus, Defuzzification and Items Ranking of Sustainable Lifestyle Construct

\begin{tabular}{|cccccc|}
\hline Expert & \multicolumn{5}{c|}{ Item } \\
\cline { 2 - 6 } 1 & $\mathrm{G} 1$ & $\mathrm{G} 2$ & $\mathrm{G} 3$ & $\mathrm{G} 4$ & $\mathrm{G} 5$ \\
2 & 0.076 & 0.025 & 0.025 & 0.127 & 0.102 \\
3 & 0.076 & 0.025 & 0.025 & 0.127 & 0.102 \\
4 & 0.229 & 0.280 & 0.025 & 0.484 & 0.102 \\
5 & 0.076 & 0.025 & 0.025 & 0.127 & 0.204 \\
6 & 0.229 & 0.025 & 0.025 & 0.178 & 0.204 \\
7 & 0.076 & 0.025 & 0.025 & 0.127 & 0.102 \\
8 & 0.076 & 0.025 & 0.025 & 0.127 & 0.102 \\
9 & 0.076 & 0.025 & 0.025 & 0.127 & 0.102 \\
10 & 0.076 & 0.025 & 0.025 & 0.127 & 0.102 \\
11 & 0.229 & 0.025 & 0.025 & 0.178 & 0.204 \\
12 & 0.076 & 0.025 & 0.025 & 0.127 & 0.102 \\
d value of each & 0.076 & 0.025 & 0.280 & 0.178 & 0.204 \\
item & 1.375 & 0.560 & 0.560 & 2.037 & 1.629 \\
Threshold (d) & & & & & \\
value of construct & & & 0.103 & & \\
Percentage of & & & & & \\
expert consensus & $75 \%$ & $92 \%$ & $92 \%$ & $92 \%$ & $67 \%$ \\
on each item & & & & & \\
Average Experts' & & & & & \\
Consensus & & & $83 \%$ & & \\
Percentage of All & & & & & \\
Items & & & & & \\
$\begin{array}{c}\text { Defuzzication } \\
\text { (Average of }\end{array}$ & & & & & \\
Fuzzy response) & 0.750 & 0.783 & 0.783 & 0.717 & 0.733 \\
(Alpha - cut) & & & & & \\
Ranking & 3 & 1 & 1 & 5 & 4 \\
\hline
\end{tabular}

The finding from the Sustainable Lifestyle construct is described in three ways; (i) the item value exceeds the threshold value (d) $=0.2$, (ii) Experts consensus percentage exceeded $75 \%$ and (iii) defuzzification value per item exceeded $\alpha$-cut $=0.5$. In the first method, items P1, P2, P4 and $\mathrm{P} 5$ exceeded the threshold value $(\mathrm{d})=0.2$ and only item P3 had a threshold value (d) $\leq 0.2$. [35] stated that if the average value and expert rating is less than the threshold value of 0.2 , then the item has gained expert consensus. All items exceeded the $75 \%$ value. All defuzzification values for each item also exceeded the $\alpha$-cut value $=0.5$. This shows that Sustainable Lifestyle items get consensus from experts. The overall findings are presented in Table 9.

The analysis, as shown in Table 9, indicates that there are items that exceed the threshold value of $0.2(>0.2)$. This means that there are inconsistencies in experts' opinions, causing the possibility of failure to reach the consensus on certain items. However, the average value of all Sustainable Lifestyle items shows a threshold value $(0.2)$, which is 0.103 . If the average threshold value (d) is obtained less than 0.2 , then the item has reached an excellent experts consensus [35]. Meanwhile, the overall percentage of expert consensus stands at $83 \%$ of the consensus value (more than $75 \%$ ), meaning that it meets the requirements of experts' consensus on this item. Additionally, all Alpha-Cut (average of fuzzy response) values exceed $\alpha$-cut $=>0.5$. According to [36]; [32] the value of alpha cut should be greater than 0.5 and if less than 0.5 , then it should be deleted. The finding of this analysis shows that the items of Sustainable Lifestyle construct achieved a good agreement among experts. Items agreed by experts were sorted according to rankings, as shown in Table 10.

Table 10. Item Position Based on Ranking (Sustainable Lifestyle)

\begin{tabular}{|lc|}
\hline \multicolumn{1}{|c|}{ Item } & Rank \\
\hline \hline G1: We need to know a sustainable lifestyle. & 3 \\
G2: Sustainable lifestyles need to be practised by us. & 1 \\
G3: Sustainable life is essential to us. & 1 \\
G4: Nature needs us to take good care of it. & 5 \\
G5: The technology development needs to be & 4 \\
consistent with a sustainable lifestyle. & \\
\hline
\end{tabular}

The highest to lowest expert's consensus rating is G2, G3, G1, G5 and G4. Positioned first is item G2: Sustainable lifestyles need to be practiced by us, equally shared with G3: Sustainable life is very important to us. We are consistently encouraged to practice a sustainable, environmentally friendly or green lifestyle [56]. Therefore, awareness of sustainable practices among individuals is capable of forming sustainable communities that leads to better preservation and conservation of environment by ensuring that development is carried out in a sustainable manner [63]. Practicing this sustainable consumption not only contributes to a healthier environment and preserves the greenery but also saves expenses [64]. The [65] themed Reducing Risks, Promoting Healthy Life reported that most of the factors of death are related to lifestyle, especially the level of consumption. Increment in chronic diseases such as obesity, hypertension, diabetes, heart disease and cancers are associated with an over-consumption of food or over nutrition, especially in foods that contains high calories and fat. In addition, 
natural disasters that often occur unexpectedly have given the community some awareness of the importance of protecting and cherishing nature [56].

Meanwhile, G1 premised that we need to know sustainable lifestyle. A sustainable lifestyle is very important in society. Congruently, Malaysia also hopes to create a sustainable society, though the level of knowledge and practice of sustainable consumption remains low. Environmental care is essential to raise awareness and to produce individuals who have positive attitudes towards the environment [66].

Next, G5: The technology development needs to be consistent with a sustainable lifestyle. The technology that is in line with Geo-Education is known as Green technology. Green technology facilitates humans to achieve sustainable development. Green technology is also known as environmental technology and clean technology. These terms are used to refer to the same meaning and the same function. According to [67], Green technology is an initiative incorporating various methods and materials, from electricity generation techniques to environmental friendly products that are not polluting the environment, such as carbon dioxide emission. In addition, Green technology is categorized as a safe tool to be used. The function of green technology can be seen as providing a healthy environment, saving energy and natural resources as well as encouraging the use of renewable resources. This technology has proven to be more efficient as it can generate energy in a variety of ways, safely and user-friendly. This has been evidenced in developed countries that are successfully developed and implementing the technology since a long time, and supply alternative energies to the world community. In addition, Green Building Education is a part of STEM education that has created opportunities for integrating science and environmental literacy into daily environmental studies [68].

Finally, G4: Nature needs us to take a good care of it. Environmental pollution is a global problem. The use of market-based instruments such as taxes has been identified as the best way to reduce environmental problems compared to other instruments such as legal uses or environmental protection campaigns [69]. The legal approach in environmental protection has long been considered a step towards solving environmental pollution issues [70]. In the context of law, the Act 127, established over 40 years ago, is considered as a legal instrument in addressing the problem of pollution in Malaysia. However, the use of legal methods has been less successful in controlling the pollution and protecting human wellness [71].

\section{E. Cross-curricular}

The findings from the Elemental across Curriculum constructs are described in three ways, which are first, the item value exceeds the threshold value $(\mathrm{d})=0.2$, second, experts consensus percentage exceeded $75 \%$, and third, defuzzification value per item exceeded $\alpha$-cut $=0.5$. In the first method, items P1, P2, P4 and P5 exceeded the threshold value $(d)=0.2$ and only item P3 had a threshold value (d) $\leq 0.2$. In that regards, [35] stated that the average value and expert rating should be less than the threshold value of 0.2 to gain experts' consensus. All items exceeded the $75 \%$ value. All defuzzification values for each item also exceeded the $\alpha$-cut value $=0.5$. This indicates that items in Sustainable Lifestyle get consensus from experts. The overall findings are presented in Table 11.

Table 11. Threshold Value (d), Percentage of Experts' Consensus, Defuzzification and Items Ranking of Cross-Curricular Construct

\begin{tabular}{|c|c|c|c|c|c|}
\hline \multirow{2}{*}{ Expert } & \multicolumn{5}{|c|}{ Item } \\
\hline & M1 & M2 & M3 & M4 & M5 \\
\hline 1 & 0.127 & 0.051 & 0.102 & 0.102 & 0.153 \\
\hline 2 & 0.127 & 0.051 & 0.102 & 0.102 & 0.153 \\
\hline 3 & 0.178 & 0.255 & 0.204 & 0.204 & 0.153 \\
\hline 4 & 0.178 & 0.051 & 0.102 & 0.102 & 0.153 \\
\hline 5 & 0.178 & 0.051 & 0.204 & 0.204 & 0.153 \\
\hline 6 & 0.127 & 0.051 & 0.102 & 0.102 & 0.153 \\
\hline 7 & 0.127 & 0.051 & 0.102 & 0.102 & 0.153 \\
\hline 8 & 0.127 & 0.051 & 0.102 & 0.102 & 0.153 \\
\hline 9 & 0.178 & 0.255 & 0.204 & 0.204 & 0.153 \\
\hline 10 & 0.127 & 0.051 & 0.102 & 0.102 & 0.153 \\
\hline 11 & 0.127 & 0.051 & 0.102 & 0.102 & 0.153 \\
\hline 12 & 0.178 & 0.051 & 0.204 & 0.102 & 0.153 \\
\hline $\begin{array}{l}\text { d value of each } \\
\text { item }\end{array}$ & 1.782 & 1.018 & 1.629 & 1.629 & 1.833 \\
\hline $\begin{array}{l}\text { Threshold (d) } \\
\text { value of construct }\end{array}$ & 0.132 & & & & \\
\hline $\begin{array}{l}\text { Percentage of } \\
\text { expert consensus } \\
\text { on each item }\end{array}$ & $100 \%$ & $83 \%$ & $67 \%$ & $67 \%$ & $100 \%$ \\
\hline Average Experts' & & & & & \\
\hline $\begin{array}{c}\text { Consensus } \\
\text { Percentage of All } \\
\text { Items }\end{array}$ & $83 \%$ & & & & \\
\hline $\begin{array}{c}\text { Defuzzication } \\
\text { (Average of } \\
\text { Fuzzy response) } \\
\text { (Alpha - cut) }\end{array}$ & 0.717 & 0.767 & 0.733 & 0.733 & 0.700 \\
\hline Ranking & 4 & 1 & 2 & 2 & 5 \\
\hline
\end{tabular}

As shown in Table 11, there are values that exceed the threshold value of $0.2(>0.2)$. This means that there is inconsistency in expert opinions and does not reach consensus on certain items. However, the average value of Cross-Curricular items shows a threshold value of (0.2) $<0.2$, which is 0.132 . If the average threshold value (d) is obtained less than 0.2 , then the item is considered to reach a good expert agreement [35]. Meanwhile, the overall percentage of expert consensus stands at $83 \%$ (more than $75 \%$ ), meaning that it meets the requirement of experts' consensus on this item. Additionally, all Alpha-Cut (average of fuzzy response) values exceed $\alpha$-cut $=>0.5$. 
According to [36], [32] the value of alpha cut should be greater than 0.5 and if less than 0.5 , then it should be dropped. The findings of this analysis show that Cross-Curricular items have been agreed by experts. Items agreed by the expert were sorted according to rankings, as shown in table 12.

Table 12. Item Position Based on Ranking (Cross-Curricular)

\begin{tabular}{|ll|}
\hline \multicolumn{1}{|c|}{ Item } & Rank \\
\hline \hline $\begin{array}{l}\text { M1: Geo-Education can be taught on various } \\
\text { subjects. }\end{array}$ & 4 \\
M2: Geo-Education can be cross-curricular. & 1 \\
M3: Various techniques can be introduced for & 2 \\
Geo-Education teaching. & 2 \\
$\begin{array}{l}\text { M4: Geo-Education is suitable as a cross-curricular } \\
\text { element. }\end{array}$ & 5 \\
$\begin{array}{l}\text { M5: Geo-Education is suitable for teaching and } \\
\text { learning of all subjects in school. }\end{array}$ & 5 \\
\hline
\end{tabular}

Rankings from the highest to lowest expert approval ratings were M2, M3 and M4, M1, and M5. Item M2: Geo-Education can be cross-curricular. Cross-curricular elements (EMKs) emphasize value in a variety of subjects. The application of Environmental Education across the curriculum is defined as a process of integrating environmental elements into the teaching and learning process for all subjects, inside and outside the classroom [72]. As such, the MOE is actively promoting Environmental Education in all schools by applying it across the curriculum as early as kindergarten to primary and secondary levels [73]. Elements in the EMK are as follows: language, science and technology, information and communication technology, positive values, patriotism, creativity and innovation, entrepreneurship, financial education, road safety and global sustainability.

Meanwhile, M3: Various techniques can be introduced for Geo-Education teaching, and M4: Geo-Education is suitable as a cross-curricular element. [74] stated that the application of Environmental Education should focus on using a variety of methods and techniques to make the teaching enjoyable and provide the opportunity for students to actively engage in the sessions without feeling overwhelmed and bored. The teachers should provide rich and varied learning challenges relevant to their objectives, activities that encourage student engagement through experience-based learning, open learning environment, supportive and fun, programs that bring students into the natural environment, becoming a role-model of responsible behaviour towards the environment. As facilitators, teachers should provide opportunities for individual and cooperative learning, a variety of approaches (incentives, inquiry), innovative and creative problem-solving of key issues, as well as encourage initiative- and free learning [75]. Accordingly, the Department of Environment has introduced more informal special programs for students such as the Environmental Awareness Camp, Nature Hero Project and Environmental Recreation Project [76]. Furthermore, Sustainable Schools were introduced to create a school environment that emphasizes environmental preservation and conservation in the aspects of management, curriculum, co-curriculum and greening in schools [74].

Furthermore, M1: Geo-Education can be taught on various subjects. Geo-Education can be taught from the lowest until the highest education level. At the higher institution level, it is recommended that the courses related to environmental education to be introduced, that students must complete according to their profile, as well as ensure appropriate training for different subjects [77]. Science, Technology, Engineering and Mathematics (STEM) approach is defined as "... Teaching and Learning processes that apply STEM knowledge, skills and values through inquiry, problem-solving, or projects in the context of daily life, the environment, as well as local and global societies" [78]. These aim to make students more socially, economically and environmentally responsible [79].

Finally M5: Geo-Education is suitable for teaching and learning of all subjects in school. Student's literacy and school performance on the environment are higher in schools that have shifted to advanced certification [80]. Therefore, teachers need to ensure that they have knowledge and understanding of environmental concepts [81], in-depth awareness of issues, regulation and education of the environment as well as creative thinking ability and delivering knowledge of Environmental Education.

\section{Reliability}

To achieve reliability between experts, average congruency percentage (ACP) was used [47] Meanwhile; Waltz suggests that ACP values should reach 90 percent [35]. All items in this study reached the required level, as indicated in Table 13. 
Table 13. Experts' Consensus Percentage for All Items

\begin{tabular}{|c|c|c|}
\hline Construct & Item & Percentage \\
\hline Primer & $\begin{array}{l}\text { P1: Geo-Education should be introduced to trainee teachers through the special module. } \\
\text { P2: There are requirements in terms of learning outcomes for the Geo-Education module. } \\
\text { P3: Technology applications need to be embedded in Geo-Education learning. } \\
\text { P4: An appropriate approach should be applied for the Geo-Education module. } \\
\text { P5: Geo-Education needs to be understood by trainee teachers. }\end{array}$ & $\begin{array}{c}96.7 \% \\
95 \% \\
100 \% \\
98.3 \% \\
93.3 \%\end{array}$ \\
\hline $\begin{array}{l}\text { Natural } \\
\text { Ecosystem }\end{array}$ & $\begin{array}{l}\text { E1: The natural ecosystem is an essential element of Geo-Education. } \\
\text { E2: We live in a natural ecosystem. } \\
\text { E3: The natural ecosystem needs to be well preserved. } \\
\text { E4: There is a responsibility to protect the natural ecosystem. } \\
\text { E5: We are entrusted to protect the natural ecosystem. }\end{array}$ & $\begin{array}{l}93.3 \% \\
95 \% \\
98.3 \% \\
95 \% \\
96.7 \%\end{array}$ \\
\hline $\begin{array}{l}\text { Issues and } \\
\text { Problems }\end{array}$ & $\begin{array}{l}\text { S1: There are frequently debated issues in Geo-Education. } \\
\text { S2: Geo-Education takes place around us. } \\
\text { S3: Environmental pollution is a significant issue of Geo-Education. } \\
\text { S4: Global warming is an issue in Geo-Education. } \\
\text { S5: Geo-Education issues are very relevant to educational institutions. }\end{array}$ & $\begin{array}{l}90 \% \\
91.7 \% \\
91.7 \% \\
88.3 \% \\
91.7 \%\end{array}$ \\
\hline $\begin{array}{l}\text { Sustainable } \\
\text { Lifestyle }\end{array}$ & $\begin{array}{l}\text { G1: We need to know a sustainable lifestyle. } \\
\text { G2: Sustainable lifestyles need to be practised by us. } \\
\text { G3: Sustainable life is significant to us. } \\
\text { G4: Nature needs us to take good care of it. } \\
\text { G5: The technology development needs to be consistent with a sustainable lifestyle }\end{array}$ & $\begin{array}{l}95 \% \\
98.3 \% \\
98.3 \% \\
91.7 \% \\
93.3 \%\end{array}$ \\
\hline $\begin{array}{l}\text { Cross-Curricular } \\
\text { Elements }\end{array}$ & $\begin{array}{l}\text { M1: Geo-Education can be taught on various subjects. } \\
\text { M2: Geo-Education can be cross-curricular. } \\
\text { M3: Various techniques can be introduced for Geo-Education teaching. } \\
\text { M4: Geo-Education is suitable as a cross-curricular element. } \\
\text { M5: Geo-Education is suitable for teaching and learning of all subjects in school. }\end{array}$ & $\begin{array}{l}91.7 \% \\
96.7 \% \\
93.3 \% \\
93.3 \% \\
90 \%\end{array}$ \\
\hline & Total & $90 \%$ \\
\hline
\end{tabular}

\section{Conclusions}

In the context of Quality Education (SDG-4), sustainable development should be embedded in teaching and learning. The emphasis and appreciation of sustainable development in education should be given the priority in addressing sustainability issues in line with SDG-4. Education plays a crucial role in addressing all of the goals of SDG-4 [34]. After reviewing the experts' opinions on the five Geo-Education constructs, this study has successfully developed this module with a strong consensus. The constructs of Primer, Natural Ecosystems, Sustainable Lifestyle, Issues and Problems as well as Cross-Curricular Elements, were successfully developed as the basis for the construction of the Geo-Education module. Each educational module, planning and policy needs organized and well-planning strategies to benefit the country [82]. This expert consensus is enough according to [83] that between six and twelve members are ideal for Delphi technique.

\section{Acknowledgments}

This work was supported by the RIMC-UUM Code SO: 14344

\section{REFERENCES}

[1] Reports OECD https://www.oecd.org/unitedstates/publicati onsdocuments/reports/

[2] Mahat, Hanifah, et al. "Pendidikan Pembangunan Lestari-Hubungan kesedaran antara ibu bapa dengan pelajar." GEOGRAFIA OnlineTM Malaysian Journal of Society and Space, vol. 10, no. 5, pp. 71-84, 2014.

[3] Jabatan Alam Sekitar, Kementerian Pelajaran Malaysia, Institut Alam Sekitar dan Pembangunan (LESTARI) (2012) Asas pembentukan Sekolah Lestari Anugerah Alam Sekitar. (Ed.ke-3)[The foundations of the School of the Environment Award (Ed.-3).]. Jabatan Alam Sekitar, Putrajaya.

[4] Saleh, Mohamad, and Mohamad Saifudin. "Media and Environmental Non-Governmental Organizations (ENGOs) 
Roles in Environmental Sustainability Communication in Malaysia." Discourse and Communication for Sustainable Education, vol. 8, no. 1, pp. 90-101, 2017.

[5] Kwami, Husayni Idi, et al. "Sustainable operation practices: The case of Universiti Kebangsaan Malaysia." Journal of Engineering Science and Technology, no. 12, pp. 74-85, 2017.

[6] Wooltorton, Sandra, et al. "Sustainability and action research in universities." International Journal of Sustainability in Higher Education, 2015.

[7] Wee, Maurice I., et al. "Awareness and Attitudes Towards Sustainable Development Amongst Higher Education Students in Penang, Malaysia." Handbook of Theory and Practice of Sustainable Development in Higher Education. Springer, Cham, pp. 49-64, 2017.

[8] Brocx, M., and V. Semeniuk. "The '8Gs' - a blueprint for Geoheritage, Geoconservation, Geo-education and Geotourism." Australian Journal of Earth Sciences, vol. 66, no. 6, pp. 803-821, 2019.

[9] National Geography Society, [Online]. Available: https://www.nationalgeographic.org/

[10] United Nations Sustainable Development, [Online]. Available:

https://www.un.org/sustainabledevelopment/sustainable-

[11] Mukaddes, M., and M. F. Agnello. "Sustainability/GREEN: Challenges and changes for educators and the engineering curriculum." American Society for Engineering Education (ASEE) Annual Conference and Exposition Proceedings, 2009.

[12] Fien, John, and Daniella Tilbury. "The global challenge of sustainability." Education and sustainability: Responding to the global challenge, no. 1, 2002.

[13] UNESCO, 2010

[14] Fielding, Kelly S., and Brian W. Head. "Determinants of young Australians' environmental actions: The role of responsibility attributions, locus of control, knowledge and attitudes." Environmental Education Research, vol. 18, no. 2, pp. 171-186, 2012.

[15] Foo, K. Y. "A vision on the role of environmental higher education contributing to the sustainable development in Malaysia." Journal of Cleaner Production, no. 61, pp. 6-12, 2013.

[16] Ab Bakar, Hazura Binti. "Hubungan antara penghayatan agama, nilai hidup dan pengetahuan alam sekitar pelajar muslim dengan sikap dan tingkah laku." Universiti Sains Malaysia., 2009.

[17] Ferreira, Jo-Anne, John Fien, and D. Heck. "Learning for a sustainable environment: workshop guide for teacher educators." 1997.

[18] Omar Osman, Salfarina Abdul Gapor, \& Zainal Abidin Sanusi (Eds.), Education for sustainable development. "The roles of universitiesas Regional Centres of Expertise" (Healthy Campus Series, No. 11). Pulau Pinang, Malaysia:Penerbit Universiti Sains.

[19] Laily, P. "Sustainable Use of Reality and Challenges". Serdang: Universiti Putra Malaysia, 2009.
[20] Ahmad, Mohamed Zohir, and Sharifah Norhaidah Syed Idros. "Kesediaan guru pelatih USM dalam menangani isu pembangunan lestari." Seminar Kebangsaan JPPG, 2005.

[21] Siraj, Saedah, et al. "Future projection on patriotism among school students using Delphi technique." Creative Education, vol. 3 no. 06 pp. $1053,2012$.

[22] Murray, Thomas J., Leo L. Pipino, and John P. van Gigch. "A pilot study of fuzzy set modification of Delphi." Human Systems Management, vol. 5, no. 1, pp. 76-80, 1985.

[23] Noorderhaben, N. Strategic decision making. UK: Addison-Wesley, 1995.

[24] Hsu, Hsi-Mei, and Chen-Tung Chen. "Aggregation of fuzzy opinions under group decision making." Fuzzy sets and systems, vol. 79. No. 3, pp. 279-285, 1996.

[25] Jacobs, J. Michael. "Essential assessment criteria for physical education teacher education programs: A Delphi study." pp. 2938-2938, 1997.

[26] Berliner, David C. "Describing the behavior and documenting the accomplishments of expert teachers." Bulletin of Science, Technology \& Society, vol. 24, no. 3 pp. 200-212, 2004.

[27] Akbari, Ramin, and Elham Yazdanmehr. "A Critical Analysis of the Selection Criteria of Expert Teachers in ELT." Theory \& Practice in Language Studies, vol. 4, no. 8, 2014.

[28] Turoff, Murray, and Harold A. Linstone. "The Delphi method-techniques and applications." 2002.

[29] Okoli, Chitu, and Suzanne D. Pawlowski. "The Delphi method as a research tool: an example, design considerations and applications." Information \& management, vol. 42, no. 1, pp. 15-29, 2004

[30] Gordon, Theodore J. "The real-time Delphi method." Futures research methodology version, vol. 3, pp. 19, 2009.

[31] Chu, Hui-Chun, and Gwo-Jen Hwang. "A Delphi-based approach to developing expert systems with the cooperation of multiple experts." Expert systems with applications, vol. 34, no. 4, pp. 2826-2840, 2008.

[32] Bodjanova, Slavka. "Median alpha-levels of a fuzzy number." Fuzzy Sets and Systems, vol. 157, no. 7, pp. 879-891, 2006.

[33] Jamil, Mohd Ridhuan Mohd, et al. "Application of Fuzzy Delphi Method in educational research." Saedah Siraj, Norlidah Alias, DeWitt, D. \& Zaharah Hussin (Eds.), Design and developmental research, pp. 85-92, 2013.

[34] Keesstra, Saskia, et al. "Soil-related sustainable development goals: Four concepts to make land degradation neutrality and restoration work." Land, vol. 7, no. 4, pp. 133, 2018.

[35] Waltz, Carolyn F., Ora Lea Strickland, and Elizabeth R. Lenz, eds. Measurement in nursing and health research. Springer publishing company, 2010.

[36] Tang, Chia-Wei, and Cheng-Ta Wu. "Obtaining a picture of undergraduate education quality: a voice from inside the university." Higher Education, vol. 60, no. 3, pp. 269-286, 2010 . 
[37] Tamuri, Ab Halim, Muhamad Faiz Ismail, and Kamarul Azmi Jasmi. "Komponen Asas untuk Latihan Guru Pendidikan Islam [Basic Components for Islamic Education Teacher Training]." Global Journal Al-Thaqafah, vol. 2, no. 2, pp. 53-63, 2012.

[38] Ali, Aliza, and Zamri Mahamod. "Analisis keperluan terhadap pengguna sasaran modul pendekatan berasaskan bermain bagi pengajaran dan pembelajaran kemahiran bahasa kanak-kanak prasekolah." JuKu: Jurnal Kurikulum \& Pengajaran Asia Pasifik, vol. 3, no. 1, pp. 1-8, 2017.

[39] Malaysia, Pelan Pembangunan Pendidikan, and P. M. R. Laporan Prestasi. "Kementerian Pendidikan Malaysia." 2013.

[40] Azli, Ariffin. Reka bentuk model aktiviti penggunaan lagu kanak-kanak Melayu tradisional untuk peningkatan imaginasi kreatif Pra Sekolah/Azli Ariffin. Diss. University of Malaya, 2018.

[41] Abdullah, A. Z. L. I. N. A. W. A. T. I., Sharifah Zarina Syed Zakaria, and Muhammad Rizal Razman. "Environmental Education through Outdoor Education for Primary School Children." Int. J. Malay World, no. 104, pp. 6, 2018.

[42] Agius, Christine. "The social construction of Swedish neutrality: challenges to Swedish identity and sovereignty." 2013.

[43] Cole, Laura B. "Green building literacy: a framework for advancing green building education." International Journal of STEM Education, vol. 6, no. 1, pp. 18, 2019.

[44] Richter, Barry Wilhelm, and L. O. De Sousa. "The implementation of environmental education to promote sustainability: an overview of the processes and challenges." International Journal of Sustainable Development \& World Ecology, vol. 26, no. 8, pp. 721-731, 2019.

[45] Ismail, Raja Abdullah Raja, and Daud Ismail. "Aplikasi 'Konsep 4c'Pembelajaran Abad Ke-21 Dalam Kalangan Guru Pelatih Pengajian Agama Institut Pendidikan Guru Kampus Dato'Razali Ismail." Asian People Journal (APJ), vol. 1.1, pp. 45-65, 2018.

[46] Rahman, S. N. H. A., Bujang, N. A., Bohari, M., Ajmain, M. T., Jima'ain, A. N. A. M., Roslan, N. R. I. M., \& Mohamad, A. M. "New Approach to Teaching, Islamic Studies Subject: Implementation of Integrated Dini Curriculum at Government Assisted Religious Schools." 2019.

[47] PophamWJ(1978)Criterion-referencedmeasurement.Englew oodCliffs,NJ:Prentice-Hall.

[48] Begum, Halima, et al. "Smallholder's practices towards environment sustainability." Advanced Science Letters, vol. 21, no. 6, pp. 1742-1745, 2015.

[49] Zou, Guo-An, et al. "Flavonoids from the stems of Croton caudatus Geisel. var. tomentosus Hook." Molecules, vol. 15, no. 3, pp. 1097-1102, 2010.

[50] Imaduddin, F., Li, Y., Mazlan, S. A., Sutrisno, J., Koga, T., Yahya, I., \& Choi, S. B. "A new class of magneto rheological elastomers based on waste tire rubber and the characterization of their properties". Smart Materials and Structures, vol. 25, no.11, pp. 115002, 2016.

[51] Guagnano, Gregory A., Thomas Dietz, and Paul C. Stern. "Willingness to pay for public goods: A test of the contribution model." Psychological Science, vol. 5. No. 6 , pp. 411-415, 1994.

[52] Othman, Mohd Yusof Hj. "Media dan isu alam sekitar (media and the issues of environment)." Jurnal Hadhari: An International Journal, vol. 2, no. 2, pp. 1-17, 2010.

[53] Yob, Johara Mohd, et al. "Nipah virus infection in bats (order Chiroptera) in peninsular Malaysia." Emerging infectious diseases, vol. 7, no. 3, pp. 439, 2001.

[54] Khalid, Shah, et al. "Organic matter management in cereals based system: Symbiosis for improving crop productivity and soil health." Sustainable Agriculture Reviews 29. Springer, Cham, pp. 67-92, 2019.

[55] The Department of Environment. Ministry of Energy, Science, Technology, Environment \& Climate Change [Online]. Available: https://www.doe.gov.my/portalv1/en/

[56] Pereira, Júnior, et al. "Didactic resources as a geo-education strategy: a means to foster geotourism in the Pathways of the South Canyons Geopark project." Applied Tourism, vol. 4. No. 2, pp. 1-10, 2019.

[57] Kioupi, Vasiliki, and Nikolaos Voulvoulis. "Education for sustainable development: A systemic framework for connecting the SDGs to educational outcomes." Sustainability, vol. 11, no. 21, pp. 6104, 2019.

[58] Liew Abdullah, Nurul Hidayah, Haryati Shafii, and Ta Wee Seow. "Pengetahuan murid dan perkaitan ibu bapa terhadap kesedaran alam sekitar: satu kajian awal." Jurnal Teknologi (Sciences \& Engineering), vol. 64. no. 1, pp. 51-57, 2013.

[59] Rahman, Haliza Abdul. "Usaha Dan Cabaran Dalam Mengaplikasikan Pendidikan Alam Sekitar Dalam Sistem Persekolahan Di Malaysia (Efforts and Challenges in the Application of Environmental Education in Malaysian School System)." Asian Journal of Environment, History and Heritage, vol. 1, no. 2, 2018.

[60] Liew Abdullah, Nurul Hidayah, Haryati Shafii, and Ta Wee Seow. "Pengetahuan murid dan perkaitan ibu bapa terhadap kesedaran alam sekitar: satu kajian awal." Jurnal Teknologi (Sciences \& Engineering) vol. 64, no. 1, pp. 51-57, 2013.

[61] Mustakim, Nur Syuhada, Muhammad Wafi Ramli, and Chan Ngai Weng. "Kesedaran komuniti terhadap isu pencemaran sungai di Sungai Pinang, Pulau Pinang (The community awareness towards river pollution issue in Sungai Pinang, Pulau Pinang)." Geografia-Malaysian Journal of Society and Space, vol. 15, no. 3, 2019.

[62] Sugiarto, Ari. "Utilization of Coconut Oil (Cocos nucifera L.) For Provoke the Presence of Ants (Hymenoptera: Formicidae)." 2018

[63] Ibrahim, Mohamad Nasir Mohamad, et al. "Copper (II) biosorption on soda lignin from oil palm empty fruit bunches (EFB)." Clean-Soil, Air, Water, vol. 37. No. 1, pp. 80-85, 2009.

[64] Kamil, Fuad Nik Mohd, and Noraien Mansor. "Penghidupan mapan". Universiti Malaysia Terengganu, 2007.

[65] World Health Report, 2002.

[66] Kollmuss, Anja, and Julian Agyeman. "Mind the gap: why do people act environmentally and what are the barriers to pro-environmental behavior." Environmental education 
research, vol. 8. No. 3, pp. 239-260, 2002.

[67] Kamarudin, Abu Bakar, et al. "Green technology compliance in Malaysia for sustainable business development." Journal of Global Management, vol. 2, no. 1, pp. 55-65, 2011.

[68] Cole, Laura B. "Green building literacy: a framework for advancing green building education." International Journal of STEM Education, vol. 6, no. 1, pp. 18, 2019.

[69] Azemi, Azwanis, et al. "Cukai Alam Sekitar: Pelaksanaan, Penjagaan Alam Sekitar dan Sistem Cukai yang Cekap." BITARA International Journal of Civilizational Studies and Human Sciences, vol. 2, no. 4, pp. 1-15, 2019.

[70] Sulaiman, Abdullah, and Muhammad Rizal Razman. "A comparative study on the International and Islamic Law: Focusing on the transboundary liability and trespass for better living environment in urban region." Social Sciences, vol. 5, no. 3, pp. 213-218, 2010.

[71] Wahab, Harlida Abdul, and Alias Azhar. "Halalan Tayyiban dalam Kerangka Perundangan Malaysia." KANUN 1, pp. 103-120, 2014.

[72] Sharif, Ahmad Mohamad, and Kong Meow San. "The Invention Curriculum: A Malaysian Experience". Innodata Monographs, vol. 11, 2001.

[73] Salih, Maria, and Hazinah Nor Hanipah. "Penerapan Pendidikan Alam Sekitar Merentas Kurikulum di Kalangan Guru Sekolah Menengah." 2009.

[74] Bean, John C. Engaging ideas: The professor's guide to integrating writing, critical thinking, and active learning in the classroom. John Wiley \& Sons, 2011.

[75] Hashim, Shahabuddin, Rohizani Yaakub, and Mohd Zohir Ahmad. Pedagogi: strategi dan teknik mengajar dengan berkesan. PTS Professional, 2007.
[76] Mahyuddin, Rahil, et al. "The incorporation of thinking skills in the school curriculum." Kajian Malaysia, vol. 22, no. 2, pp. 23-33, 2004.

[77] Paula-Acosta, Caridad Amado, Jesús Pérez-López, and Julio Jesús Sierra-Socorro. "La educación ambiental con enfoque integrador. Una experiencia en la formación inicial de profesores de matemáticay física." Revista Electrónica Educare, vol. 23, no.1, pp. 181-202, 2019.

[78] Baharin, Norlizawaty, Nurzatulshima Kamarudin, and Umi Kalthom Abdul Manaf. "Integrating STEM education approach in enhancing higher order thinking skills." International Journal of Academic Research in Business and Social Sciences, vol. 8, no. 7, pp. 810-821, 2018.

[79] Vasodavan, Vinothini, Dorothy DeWitt, and Norlidah Alias. "TPACK IN HIGHER EDUCATION: ANALYSIS OF THE COLLABORATIVE TOOLS USED BY LECTURERS." JuKu: Jurnal Kurikulum \& Pengajaran Asia Pasifik, vol. 7, no. 1, pp. 9-17, 2019.

[80] Goldman, Daphne, et al. "Influence of 'green school certification'on students' environmental literacy and adoption of sustainable practice by schools." Journal of cleaner production, vol. 183, pp. 1300-1313, 2018.

[81] Zak, Kevin M., and Bruce H. Munson. "An exploratory study of elementary preservice teachers' understanding of ecology using concept maps." The Journal of environmental education, vol. 39, no 3, pp. 32-46, 2008.

[82] Yaakob, M,F,M., Yunus, \& Jafar, M,F. (2020). Evaluate the Activities of $1 \mathrm{M} 1 \mathrm{~S}$ and Co-curriculum in Kedah: Insight from Teachers. Universal Journal Educational Research $8.183-190$

[83] Einhorn, H. J., \& Hogarth, R. M. (1978). Confidence in judgment: Persistence of the illusion of validity. Psychological Review, 85(5), 395-416. https://doi.org/10.1 037/0033-295X.85.5.395 